\title{
Hybrid Model for Uncertainty Assessment in Open Pit Optimization
}

\begin{abstract}
DEJAN R. STEVANOVIĆ, University of Belgrade, Faculty of Mining and Geology, Belgrade MIRJANA V. BANKOVIĆ, University of Belgrade, Faculty of Mining and Geology, Belgrade MILICA D. PEŠIĆ-GEORGIADIS, University of Belgrade, Faculty of Mining and Geology, Belgrade LAZAR B. STOJANOVIĆ, University of Banja Luka, Faculty of Mining, Prijedor, Bosnia and Herzegovina

Original scientific paper
UDC: 622.68

DOI: 10.5937/tehnika2002161S

Today deposits are often, small in size, with poor quality and with complex structure and geometry, which makes them very difficult to mine. For this reasons, taking into account a wide range of parameters is the most important thing for the successful managing of the economically viable project. The problem is that practically, value of every parameter is strongly connected with many uncertainties. That's why, all uncertainties should be incorporated in calculations in order to provide more realistic solutions. The core of pit optimization is the economic value of every block in block model. The economic block value depends on many parameters of an uncertain value. This paper presents a model for calculating the economic block value and generating optimal pits that can be used for the uncertainty assessment. The developed model is a combination of conventional (deterministic) and stochastic approaches. The presented model takes into account the uncertainty of parameters for the determination of block value. The paper also makes a comparison between ultimate pits generated by conventional and stochastic models of economic block value. This comparison can be used for the uncertainty assessment associated with the optimization of pit limits for coal or metal deposits.
\end{abstract}

Key words: pit optimization; economic block value; uncertainty assessment; stochastic model

\section{INTRODUCTION}

Every component of any mining project has a certain degree of uncertainty that can be divided into two main categories: technical risks and commercial risks. Technical risks include resource grade and variability, production rates, operating capital cost, metallurgical performance and product quality. On the other hand, commercial risks include commodity prices, exchange rates, marketing, external cost, and political risks [1].

General characteristic of current approach in optimization and pit planning, is based on deterministic approach and adoption of the input parameters. This means that, after extensive analysis, the value of each input parameter is adopted as a unique correct value.

Author's address: Dejan Stevanović, University of Belgrade, Faculty of Mining and Geology, Belgrade, Đušina 7

e-mail: dejan.stevanovic@i rgf.bg.ac.rs

Paper received: 16.03.2020.

Paper accepted: 20.03.2020.
This value can be determined in real time when the analysis is done, or it can be estimated with an attempt to approximate the value of a particular parameter and its trend in the future, but in any case adopted value is unique and immutable, i.e. believed absolutely correct. Further, optimization and planning work is carried on under the assumption that the geological boundaries, the distribution of quality, technology and mining and processing parameters, as well as the potential economic parameters, are fully known. These algorithms are known as conventional approach in literature. The disadvantages of conventional algorithms lie in the fact that they do not take into account the uncertainty related to the input parameters optimization. This way, the risk associated with uncertainties cannot be properly evaluated, a fact that often keeps mining companies, far from meeting their basic commercial goals.

There are many examples of mines, where planning has been based on the most optimistic estimation approach (without a proper uncertainty assessment) and, at the end, the companies encountered a financial disaster. Morley, Snowden and Day [2] indicated that 
$70 \%$ of small mining companies in South Africa had mainly failed during the 1980's just because of having overestimated the reserve tonnage and grade. The importance of uncertainty assessment is emphasized by the work of many authors. Erdem, Güyagüler and Demirel [3] show how proper analysis of uncertainty in financial evaluation can help decision makers to prevent possible errors.

It should also be noted, that the elimination of risk (at the expense of the project value) is not the ultimate goal. The degree of risk the company is prepared to expose itself to, depends to large extent on its decisionmaking behavior [4].

One of the most important phases in every mining project is the optimization of pit limits. The objective function of the optimization is the maximization of the profit yielded by the pit, calculated as the cumulative value of all the material (ore and waste). There are many algorithms for optimizing pit limits. LerchsGrossmann (LG) method is the mostly used one, and it represents conventional industrial standards. LG method guarantees finding the optimal pit (optimal for a given set of parameters) in three dimensions [5]. The method works with only two types of information: the economic block value and the arcs (relation between two blocks). The economic block value (EBV) depends on many parameters with an uncertain value.
For dealing with various mining and geology problems, stochastic approach is suggested by many authors [6-9]. This paper presents a stochastic model for calculating the EBV. The presented model takes into account the uncertainty of parameters for the determination of block value. The paper also makes a comparison between ultimate pits generated by conventional and stochastic models of EBV, which can be used for the uncertainty assessment associated with the optimization of pit limits.

In engineering sense, the problem of optimization of the open pit limits, comes down to the definition of the economic block model. In this respect, the source of uncertainty that occur while creating the economic block model is the source of uncertainty for the pit optimization process [6].

There are several ways of writing an expression for the EBV. In general, the value of the block is equal to the value of the ore in block (that can be excavated and processed), reduced by all coast (mining, processing, selling etc.). Since the value of parameters that determine the $\mathrm{EBV}$, are variable (they can change depending on applied methodology or through life of mine), the EBV can't be specified with single correct value. Therefore, these parameters are often main sources of uncertainty in mining and can be classified in four categories of uncertainty, Table 1 :

Table 1. Sources of uncertainties relevant to block value

\begin{tabular}{|l|l|l|l|}
\hline Geological Uncertainty & Market Uncertainty & $\begin{array}{l}\text { Uncertainty in Costs } \\
\text { Estimation }\end{array}$ & Recovery Uncertainty \\
\hline Geometry of orebody & Price of product $\left(€ / \mathrm{m}^{3} ; € / \mathrm{t} ; € / \%\right)$, & Mining costs $\left(€ / \mathrm{m}^{3}\right)$ & Mining recovery $(\%)$ \\
\hline Units of product - Grade $(\% ; \mathrm{g} / \mathrm{t})$ & Exchange rate $(\$ / € ; \$ / \mathfrak{£})$ & Milling costs $\left(€ / \mathrm{m}^{3}\right)$ & Milling recovery $(\%)$ \\
\hline Specific gravity $\left(\mathrm{t} / \mathrm{m}^{3}\right)$ & $/$ & $/$ & $/$ \\
\hline
\end{tabular}

Geological uncertainty has been regarded as the major cause for not meeting project expectations as explained by Dimitrakopoulos, Farrelly and Godoy [10] and Abdel and Dimitrakopoulos [11]. Many authors have indicated that mineral resources and ore reserve reports generally contain a single tonnage and grade values. The tonnage and grade values do not contain any reference to the potential uncertainties in the estimations. Morley, Snowden and Day noted that „Any resource and reserve estimation is guaranteed to be wrong. Some however, are less wrong than others ${ }^{\text {ee }}[2]$.

The geological uncertainty consists of three major sources:

- Boundaries of mineral reserves,

- Density of the ore body,

- Grade of the ore body

Boundaries of mineral reserves can be more or less well detected. This uncertainty is usually caused by a lack of information.
Density and grade of the whole ore body is determined by using the results of the drill holes. Even if we assume that the sampling procedure and the estimation of a density are properly performed, obtained value, in every point of the mineral deposit, will not be the correct one. Therefore, density and grade of the ore body are considered to be very important sources of uncertainties.

Many authors suggest, that the best way of dealing with geological uncertainties, is the utilization of stochastic simulated ore bodies. Dimitrakopoulos, Farrelly and Godoy [10] showed the impact of geological uncertainties on Net Present Value (NPV). They showed that if the conventionally constructed open pit design is tested against equal probable simulated scenarios of the ore body, its performance will probably not meet the expectations.

The conventionally expected NPV of the mine has a 2 to 4 percent chance to materialize, while it is 
expected to be $25 \%$ less than forecasted. Note that in a different example, the opposite could be the case [10].

Volatile nature of the market (especially metal market) makes price forecasting one of the main sources of uncertainty. Many factors influence the market price: the demand, the supply, speculation, news events, dividend payouts etc. Rendu indicated that the most important risk factor is the lack of knowledge about the future price of product mining [12]. Much effort has been invested to reduce price forecasting uncertainty, but usually this ends up in poor results. The most accurate price forecasting can be performed using a combination of technical and fundamental approaches. The technical approach consists of analyzing historical prices, studying long-term trends and shortterm variability and developing a statistical model. The fundamental approach consists of forecasting supply and demand.

The price uncertainty is consider by numerous developed methods. Baek, Yosson and Park [13] presented a method to quantitatively represent the uncertainty included in open pit optimization results due to variation in mineral prices, Evatt et al. [14] developed method for estimation of ore reserves under mineral price uncertainty, Asad and Dimitrakopoulos [15] presented a parametric maximum flow algorithm for open pit optimization under uncertain market conditions.

In addition, uncertainties related to exchange rate variations are in the group of market uncertainty. Price in the global market is usually expressed in a single currency, which might not match the currency of the country where the raw material is exploited and where is exported. For this reason, variations of exchange rates are of great importance the financial performance of a mining project.

The impact of uncertainty in cost estimation and recovery is, in most cases, less significant. The major factors for these types of uncertainty are based on technical, organizational, geological and geotechnical conditions.

\section{METHOD FOR UNCERTAINTY ASSESSMENT IN PIT OPTIMIZATION - DEVELOPMENT OF HYBRID MODEL}

As it is mentioned above, the only input for Lerchs-Grossmann (LG) method of pit optimization is the EBV for all blocks in a geological block model. Conventional (deterministic) method for optimization of pit limits produces solutions that do not incorporate uncertainty. To overcome this problem, a hybrid model was developed. The algorithm of this model is shown in Figure 1. The model generates a stochastic optimal pit shells and a conventional optimal pit shells. Stochastic optimal pit shells can be used for the uncertainty assessment, regarding optimal pit limits.

The model can be described through the following four steps:

- Defining set of input parameters

- Calculating Economic Value of Block

- Analysis and Comparison of Calculated Block Value

- Generation of Optimal Pit Shells and Assessment of Uncertainty

Step 1. In the first step, a set of input parameters for EBV is defined. The parameters are: grade of ore, specific gravity, selling price of product, mining and milling recovery, mining and milling costs.

On the basics of those parameters, stochastic and deterministic EBV will be calculated. For the deterministic (conventional) EBV, parameters have a single value, while for the stochastic EBV all parameters are defined as the probability distributions.

Step 2. For the deterministic approach, the value of one block is calculated using the equation:

$$
E B V=(\operatorname{Grade} \cdot \operatorname{Mining}(R) \cdot \operatorname{Milling}(R) \cdot \text { Price })-(\operatorname{Mining}(C)+\operatorname{Milling}(C))
$$

Where: EBV - economic block value $\left(€ / \mathrm{m}^{3}\right)$, Grade-grade of ore in block (\%), Price - price of commodity (coal, metal, $€ / \mathrm{t} ; € / \%$ ), Mining(R)-mining recovery (\%), Milling(R)-milling recovery (\%), Mi$\operatorname{ning}(\mathrm{C})-$ cost for mining a block $\left(€ / \mathrm{m}^{3}\right)$, Milling $(\mathrm{C})-$ cost of processing block $\left(€ / \mathrm{m}^{3}\right)$.

It is important to emphasize that the deterministic calculation of EBV, for all blocks in model, is automatically done, with the use of Pit optimizer (part of Surpac 6.1). The Result is a single economic value for every block in the model. For the stochastic approach, EBV is calculated using Monte Carlo simulation (MCS) on the basics of the same equation 1. The inputs for MCS are probability distributions for every parameter. MCS has the advantage of evaluating a huge number of hypothetical scenarios, which makes MCS powerful mathematical method for conducting uncertainty assessment and quantitative risk analysis in mining industry as is shown by Lane [16].

In this way, uncertainty is taken into account. The result is a set of block values (for one block) with different probability of occurring. Based on type of distribution, some probable block values are more interesting than others. For example, in normal distribution particularly interesting is the most probable block value and values of one and two standard deviation interval $(\bar{x} \pm \sigma=68.27 \%$ and $\bar{x} \pm$ $2 \sigma=95 \%$ ) around mean $(\bar{x})$ economic block value. 


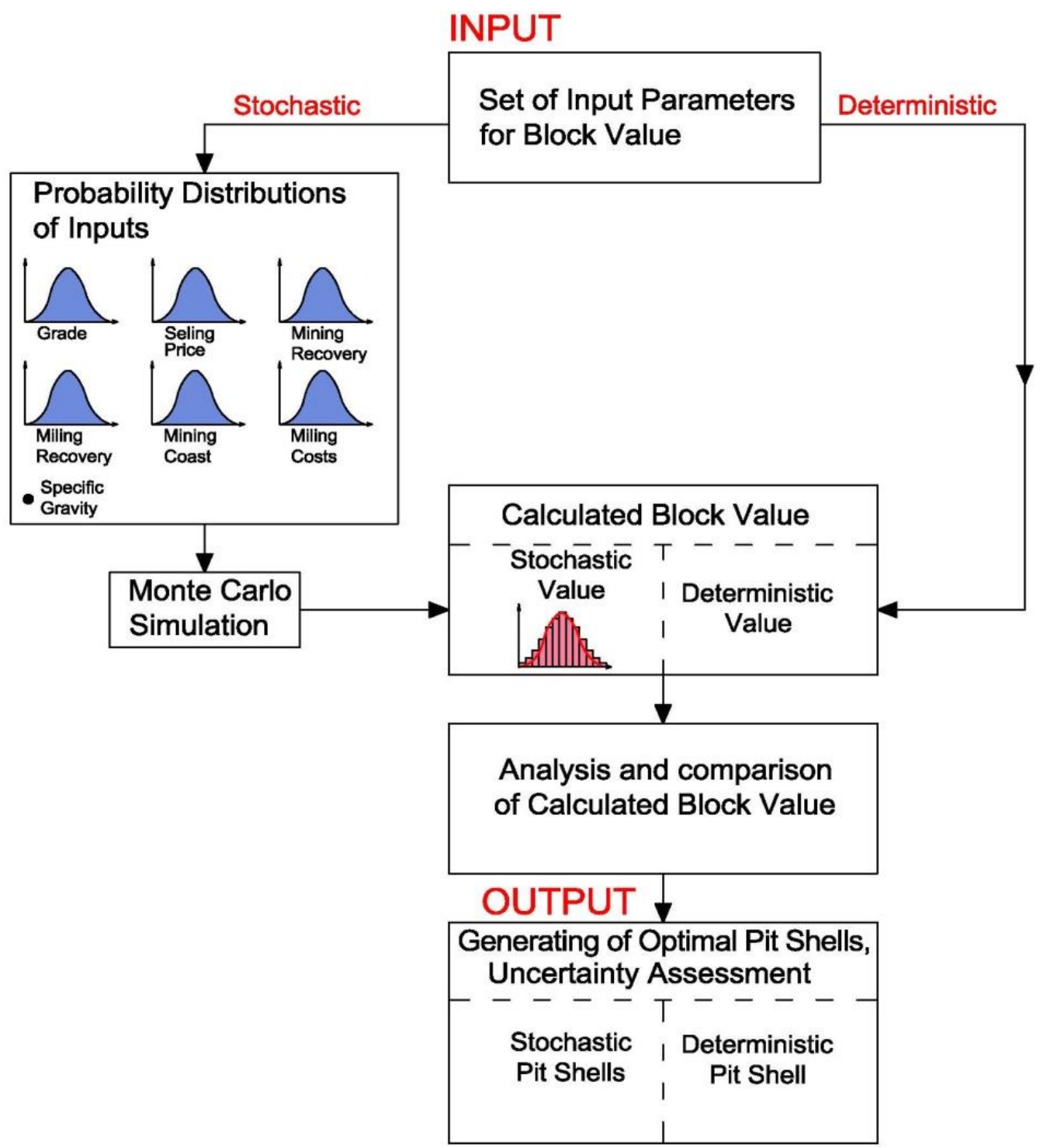

Figure 1 - Algorithm of hybrid model for uncertainty assessment in pit optimization

Step 3. In order to successfully apply the LG method and find optimal pit limits, it is essential that each block (in block model) has its economic value. For the deterministic approach, calculating EBV is easy, because for the given set of parameters, it is automatically done for every block.

In contrast, for stochastic approach, calculating EBV is much more complicated, since MCS must be done for each block (in the block model). As the block model usually consists of hundreds of thousands of blocks and the time for one simulation is measured in minutes, making calculation of simulated EBV for all blocks is a time-consuming and rather impractical procedure. To overcome this problem, a different approach is proposed in this paper. MCS (of EBV) is done only for a specific number of blocks. Obtained results (simulated EBV) are then compared with EBV (for the same blocks) determined with the deterministic approach.
Based on this comparison, the function that correlates deterministic and simulated EBV is determined. Using this function, EBV for all other blocks (for the stochastic block model) is calculated. According to this approach, it is very important that function, derived from the comparison of deterministic and simulated $\mathrm{EBV}$, can be found and that, with this function, an adequate accurate approximation (of stochastic EBV) is possible.

Step 4. After calculation of deterministic and stochastic EBV, LG algorithm is used for the optimization of pit limits. Based on the analysis we want to carry out, a different number of pits can be generated. For the deterministic calculated EBV conventional pit limits will be generated and from the stochastic EBV it is especially interesting to generate pit shell for most probable EBV and for values of one and two standard deviation interval around mean EBV $(\bar{x} \pm \sigma=68.27 \%$ and $\bar{x} \pm 2 \sigma=95 \%$ ). From generated pit shells for 
different deterministic and stochastic EBV, uncertainty assessments can be obtained.

\section{CASE STUDY OPTIMIZATION OF PIT LIMITS AND ASSESSMENT OF UNCERTAINTY}

For better understanding of developed model, case study is provided. The case study was made for iron ore deposit, but nevertheless developed hybrid model is universal and can be used for coal and other mineral deposits.

Software packages used in calculations are Pit Optimizer (module of Surpac 6.1) [17]. and for the Monte Carlo simulation, a student version of @Risk 6.1.2 was used [18].
The analyzed deposit is a real deposit, which due to confidential reasons, will not be named. Also, all parameters used in calculation, are taken from existing practice of mining iron ore deposits.

The deposit is explored with 552 drillholes. Based on drillholes a geological model is developed. Calculation with model showed reserves of 43.7 million tons of ore with an average grade of $41.6 \%$ of iron. Reserves were calculated for the cut-off value of $35 \%$ of iron in ore $[19,20]$. In order to conduct pit optimizations and uncertainty assessments, a set of required parameters is determined. For the deterministic (conventional) calculation of EBV, all parameters have a unique value (Table 2).

Table 2. Parameter set for conventional calculation of EBV

\begin{tabular}{|l|l|l|l|l|l|}
\hline $\begin{array}{l}\text { Units of product } \\
\text { Grade (\%) }\end{array}$ & $\begin{array}{l}\text { Price of product } \\
(€ / \mathrm{t}, @ 51.4 \% \mathrm{Fe})\end{array}$ & $\begin{array}{l}\text { Mining recovery } \\
(\%)\end{array}$ & $\begin{array}{l}\text { Milling recovery } \\
(\%)\end{array}$ & $\begin{array}{l}\text { Mining costs for ore } \\
\text { and waste }\left(€ / \mathrm{m}^{3}\right)\end{array}$ & $\begin{array}{l}\text { Milling costs } \\
\left(€ / \mathrm{m}^{3}\right)\end{array}$ \\
\hline $\begin{array}{l}\text { Different for } \\
\text { every block }\end{array}$ & 91.3 & 94 & 84 & 4 & 13.47 \\
\hline
\end{tabular}

Product price (iron concentrate) is an average monthly price for period from January 2000 - up to May 2013. The data is taken from the International Monetary Fund [21] and is related to China import Iron Ore Fines $62 \%$ Fe spot (CFR Tianjin port). Due to its volatile nature, prices from years 2008 and 2009 were not taken into account. For the purpose of this case study, prices of iron ore concentrate went through currency replacement, from US Dollars to Euros and they have been recalculated from 62\%_Fe to $51,4 \%$ Fe concentrate. For the stochastic approach, based on statistical analysis, probability distribution of every parameter is defined.

The basic properties of probability distributions are shown in table 3. The distribution, defined for every parameter separately, is the same for every block, except the distribution for the Grade parameter, which is defined around estimated value.

With the defined set of parameters and the probability distribution of these parameters, we can calculate EBV using both deterministic and stochastic approach. If we calculate EBV for a block that contains average grade of iron (41.6\%), using the deterministic approach (equation 1) we obtain a single value: EBV $=55,99 € / \mathrm{m}^{3}$.

With the stochastic approach based on MCS, for the same block, we obtain normal distribution of a set of probable EBV with a different probability of occurrence (Figure 2). All simulations in this case study were performed in 50.000 iterations

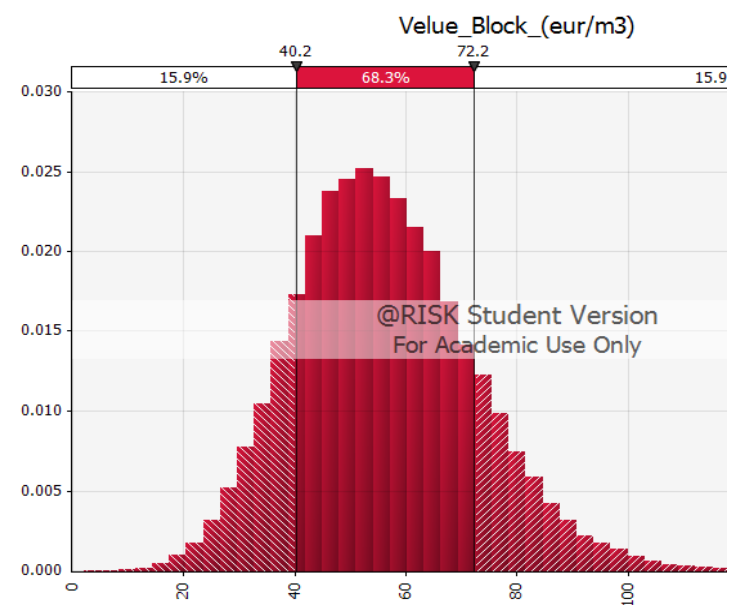

Figure 2 - Probability distribution of EBV (grade $41.6 \% \mathrm{Fe}$ )

Some values obtained from performed MCS are more interesting (relevant) than others. Minimum simulated value EBV is $2.13 € / \mathrm{m}^{3}$, while maximum EBV is $142.7 € / \mathrm{m}^{3}$. The mean value of distribution is $56.13 € / \mathrm{m}^{3}$, and the most probable EBV is $50.46 € / \mathrm{m}^{3}$. Standard deviation $(\sigma)$ for distribution is 16.09 and with a probability of $68.3 \%(\bar{x} \pm \sigma)$, the exact EBV will be in range from $40.2 € / \mathrm{m} 3$ to $72.2 € / \mathrm{m}^{3}$. With the probability of $95 \%(\bar{x} \pm 2 \sigma)$, the exact EBV will vary from $28 € / \mathrm{m}^{3}$ to $90.3 € / \mathrm{m}^{3}$. 
Table 3. Basic properties of probability distributions for calculation of EBV

\begin{tabular}{|c|c|c|}
\hline Variable parameter & $\begin{array}{l}\text { Type of distribution } \\
\text { And Histogram }\end{array}$ & Properties of distribution \\
\hline $\begin{array}{l}\text { Units of product } \\
\text { Grade } \\
(\%)\end{array}$ & 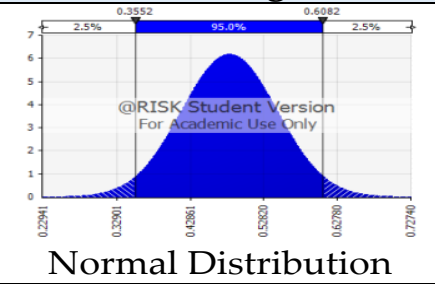 & $\begin{array}{c}\text { Mean=estimated grade value for block } \\
\text { Mode=estimated grade value for block } \\
\text { Median=estimated grade value for block } \\
\text { Standard deviation }=0.0645\end{array}$ \\
\hline $\begin{array}{c}\text { Price } \\
\text { of product } \\
(€ / \mathrm{t}, @ 51.4 \% \mathrm{Fe})\end{array}$ & Gama Distribution & $\begin{array}{c}\alpha=46.41 \\
\beta=1.968 \\
\text { Mean }=91.34 \\
\text { Mode }=89.37 \\
\text { Median }=90.68 \\
\text { Standard deviation }=13.41\end{array}$ \\
\hline $\begin{array}{c}\text { Mining recovery } \\
(\%)\end{array}$ &  & $\begin{array}{c}\text { Minimum }=0.90 \\
\text { Maximum }=1.00 \\
\text { Mean } \approx 0.941 \\
\text { Mode }=0.94 \\
\text { Median }=0.9405 \\
\text { Standard deviation } \approx 0.0187\end{array}$ \\
\hline $\begin{array}{l}\text { Milling recovery } \\
(\%)\end{array}$ & QRISK Student Version & $\begin{array}{c}\text { Minimum }=0.80 \\
\text { Maximum }=0.88 \\
\text { Mean } \approx 0.84 \\
\text { Mode }=0.84 \\
\text { Median }=0.84 \\
\text { Standard deviation } \approx 0.0176\end{array}$ \\
\hline $\begin{array}{l}\text { Mining costs } \\
\qquad\left(€ / \mathrm{m}^{3}\right)\end{array}$ & 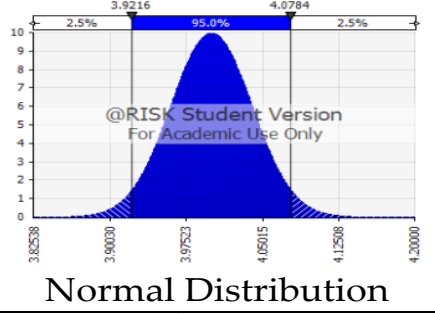 & $\begin{array}{c}\text { Minimum }=3.0 \\
\text { Maximum }=5.0 \\
\text { Mean }=4.0 \\
\text { Mode }=4.0 \\
\text { Median }=4.0 \\
\text { Standard deviation }=0.040\end{array}$ \\
\hline $\begin{array}{l}\text { Milling costs } \\
\qquad\left(€ / \mathrm{m}^{3}\right)\end{array}$ & 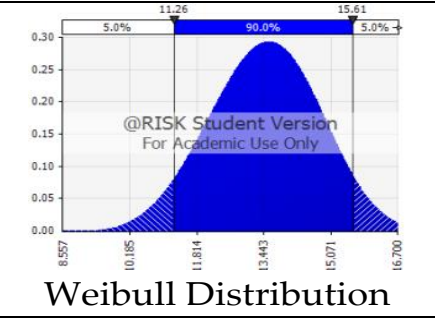 & $\begin{array}{c}\alpha=3.7961 \\
\beta=4.9516 \\
\text { Shift }=9 \\
\text { Mean }=13.4749 \\
\text { Mode }=13.5684 \\
\text { Median=13.4959 } \\
\text { Standard deviation }=1.316\end{array}$ \\
\hline
\end{tabular}

\section{ANALYSIS AND COMPARISON OF CALCULATED BLOCK VALUE}

Analysis of both approaches can be done for a set of blocks with different grade content, comparing deterministic versus simulated values. The range of grade for this analysis is specified from cut-off value in block model $(35 \% \mathrm{Fe})$ up to maximum value in block model $(65 \% \mathrm{Fe})$. Results of deterministic and simulated EBV calculation for the specified range of grade are presented

In Table 4. For deterministic approach EBV is unique for each grade value, but for stochastic approach we have two values that define the range of $(\bar{x} \pm \sigma)$. 
Table 4. Results of deterministic and simulated EBV calculation

\begin{tabular}{|l|l|l|l|l|l|l|}
\hline $\begin{array}{l}\text { Grade } \\
(\% \mathrm{Fe})\end{array}$ & Conventional Approach & \multicolumn{2}{|l|}{ Stochastic Approach } & \multicolumn{2}{l|}{$\begin{array}{l}\text { Comparison } \\
\text { Stochastic/Conventional }\end{array}$} \\
\hline $\mathrm{A}$ & $\mathrm{B}$ & $\mathrm{C}$ & $\mathrm{D}$ & $\mathrm{E}$ & $\mathrm{F}$ & $\mathrm{G}$ \\
\hline$/$ & $\begin{array}{l}\text { Deterministic EBV } \\
\left(€ / \mathrm{m}^{3}\right)\end{array}$ & $\begin{array}{l}\text { Standard Deviation } \sigma \\
(€)\end{array}$ & $\begin{array}{l}\text { EBV for } \\
\bar{x}-\sigma \\
\left(€ / \mathrm{m}^{3}\right)\end{array}$ & $\begin{array}{l}\text { EBV for } \\
\bar{x}+\sigma \\
\left(€ / \mathrm{m}^{3}\right)\end{array}$ & $\begin{array}{l}\text { Ratio } \\
\mathrm{D} / \mathrm{B}\end{array}$ & $\begin{array}{l}\text { Ratio } \\
\text { E/B }\end{array}$ \\
\hline 35 & 44.34 & 14.87 & 29.7 & 59.1 & 0.670 & 1.333 \\
\hline 40 & 53.17 & 15.72 & 37.7 & 68.7 & 0.709 & 1.292 \\
\hline 45 & 62 & 16.68 & 45.7 & 78.5 & 0.737 & 1.266 \\
\hline 50 & 70.84 & 17.57 & 53.5 & 88.4 & 0.755 & 1.248 \\
\hline 55 & 79.66 & 18.59 & 61.4 & 98.2 & 0.771 & 1.233 \\
\hline 60 & 88.5 & 19.59 & 69.2 & 108.1 & 0.782 & 1.221 \\
\hline 65 & 97.3 & 20.77 & 76.9 & 118.2 & 0.790 & 1.215 \\
\hline
\end{tabular}

As it has already been mentioned, it would be quite time-consuming and rather impractical to simulate $\bar{x} \pm \sigma$ values for all blocks in the block model. To overcome unnecessary computing, function is defined in order to approximate the $\bar{x} \pm \sigma$ of EBV, for all ore blocks in the model. Ratio of column D and column B (D/B - from table 4) defines function (Figure 3) that, relates Grade, stochastic EBV for $\bar{x}-\sigma$ and deterministic EBV. Figure 3 indicates that, the relation of grade, EBV for $\bar{x}-\sigma$ and deterministic EBV (blue line in Figure 3 ) is approximated with a polynomial function (red line in Figure 3):

$$
(D / B)=-0.0029 x^{2}+0.0425 x+0.6328
$$

Where: $(\mathrm{D} / \mathrm{B})$ is the ratio of stochastic EBV for probability distribution $\bar{x}-\sigma$ and deterministic EBV and relation of $\mathrm{X}$ value and grade is defined with equation 3.

$$
X=\frac{\text { Grade }-30}{5}
$$

Coefficient of determination, which indicates how well curve fit data points (or how accurate approximation is) in this case is $\mathrm{R}^{2}=0.9968$.

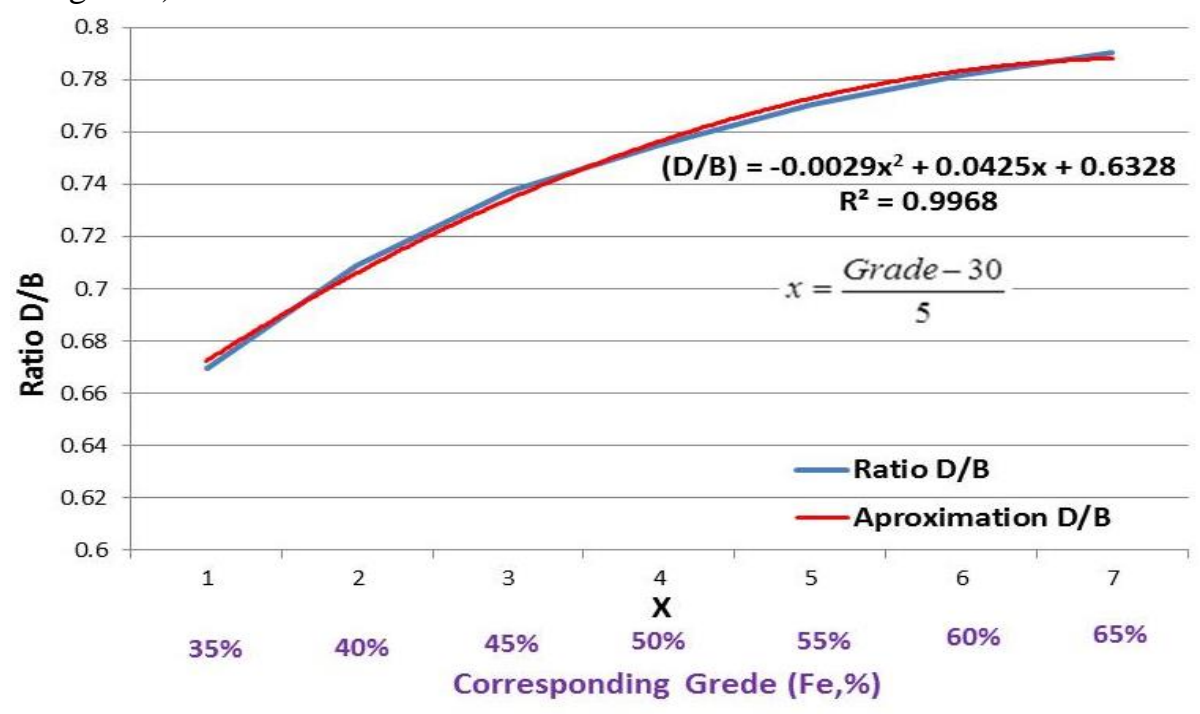

Figure 3 - Ratio and approximation of stochastic EBV for $\bar{x}-\sigma$ and deterministic EBV

Using equation 2 , for the every block in model, depending on the grade of that block, the ratio of stochastic EBV for $(\bar{x}-\sigma)$ and deterministic EBV and stochastic EBV (ratio D/B) can be calculated. Note that the $\mathrm{X}$ value from equation 2 is changed according to equation 3. By multiplying known deterministic EBV with ratio $\mathrm{D} / \mathrm{B}$, approximated $\mathrm{EBV}$ for probability of $\bar{x}-\sigma$ can be obtained.

By following the explained steps, this can be done very easily and quickly for each block in block model. Two last steps, calculating ratio $\mathrm{D} / \mathrm{B}$ and approximation of EBV for probability of $\bar{x}-\sigma$, are done 
automatically. In this case, it is done with command attribute math (Surpac 6.1), but it can also be done, for example, using Microsoft Excel, if the block model is exported to comma separated values (csv) file format.

The same procedure can be applied to calculate EBV for probability distribution of $\bar{x}+\sigma$ (average plus one standard deviation value). By comparing simulated EBV of $\bar{x}+\sigma$ (column $\mathrm{E}$ in table 4) with deterministic calculated EBV (column B in table 4) we can obtain the ratio $\mathrm{E} / \mathrm{B}$ (column $\mathrm{G}$ in table 4 ), which define function (Figure 4). This function relates grade, deterministic EBV and stochastic EBV for $\bar{x}+\sigma$.

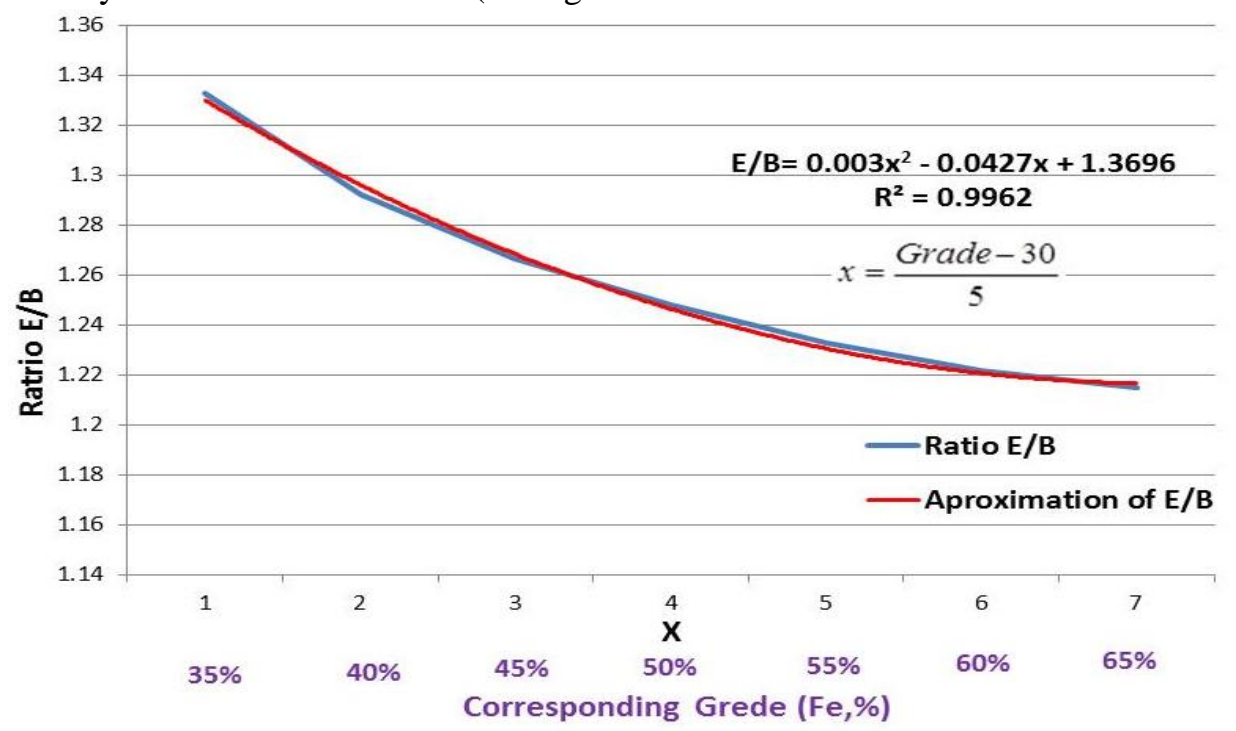

Figure 4 - Ratio and approximation of stochastic EBV for $\bar{x}+\sigma$ and deterministic EBV

In this case, the relation of stochastic EBV for $\bar{x}+$ $\sigma$ and deterministic EBV (blue line in Figure 4) is approximated, again, with polynomial function (red line in Figure 4):

$$
E / B=0.003 x^{2}-0.0427 x+1.3696
$$

Where: $(\mathrm{E} / \mathrm{B})-$ is the, relation of EBV for probability distribution of $\bar{x}+\sigma$ and deterministic EBV and relation of $\mathrm{X}$ value and grade is defined with equation 5 .

$$
X=\frac{\text { Grade }-30}{5}
$$

Coefficient of determination for this approximation is $\mathrm{R}^{2}=0.9962$.

In the same way like it has already been explained, with equation 4 , for each block in the model, depending on the grade of that block, and expression for $\mathrm{X}$ (equation 5) ratio of $\mathrm{EBV}$ for probability of $\bar{x}+\sigma$ and deterministic EBV can be calculated (ratio E/B). By multiplying known deterministic EBV with calculated ratio $\mathrm{E} / \mathrm{B}$, approximated $\mathrm{EBV}$ for probability distribution of $\bar{x}+\sigma$ can be obtained. These last two steps are also done automatically.

\section{GENERATION OF OPTIMAL PIT SHELLS AND ASSESSMENT OF UNCERTAINTY}

The result of the procedure explained in previous section is the block model with three different EBV, one deterministically calculated and two approximations for $\bar{x} \pm \sigma$. Those EBV are used for the optimization of pit limits (LG method). Generated optimal pits shells are shown in Figure 5, while Table 5 specifies the details of their performance.

As shown on Figure 5, optimal pit shell: generated with deterministic calculated EBV is marked as Pit_1, generated with approximation EBV of probability $\bar{x}-$ $\sigma$ is marked as Pit_2, generated with approximation EBV of probability $\bar{x}+\sigma$ is marked as Pit_3

Table 5. Basic performance of generated pits

\begin{tabular}{|l|l|l|l|}
\hline Optimal Pit & Pit 1 & Pit 2 & Pit 3 \\
\hline Ore Mass (t) & 36.021 .000 & 32.604 .000 & 36.950 .000 \\
\hline Waste Volume $\left(\mathrm{m}^{3}\right)$ & 61.401 .000 & 45.707 .000 & 66.249 .000 \\
\hline NPV of Pit & 290.355 .000 & 192.203 .000 & 401.160 .000 \\
\hline
\end{tabular}




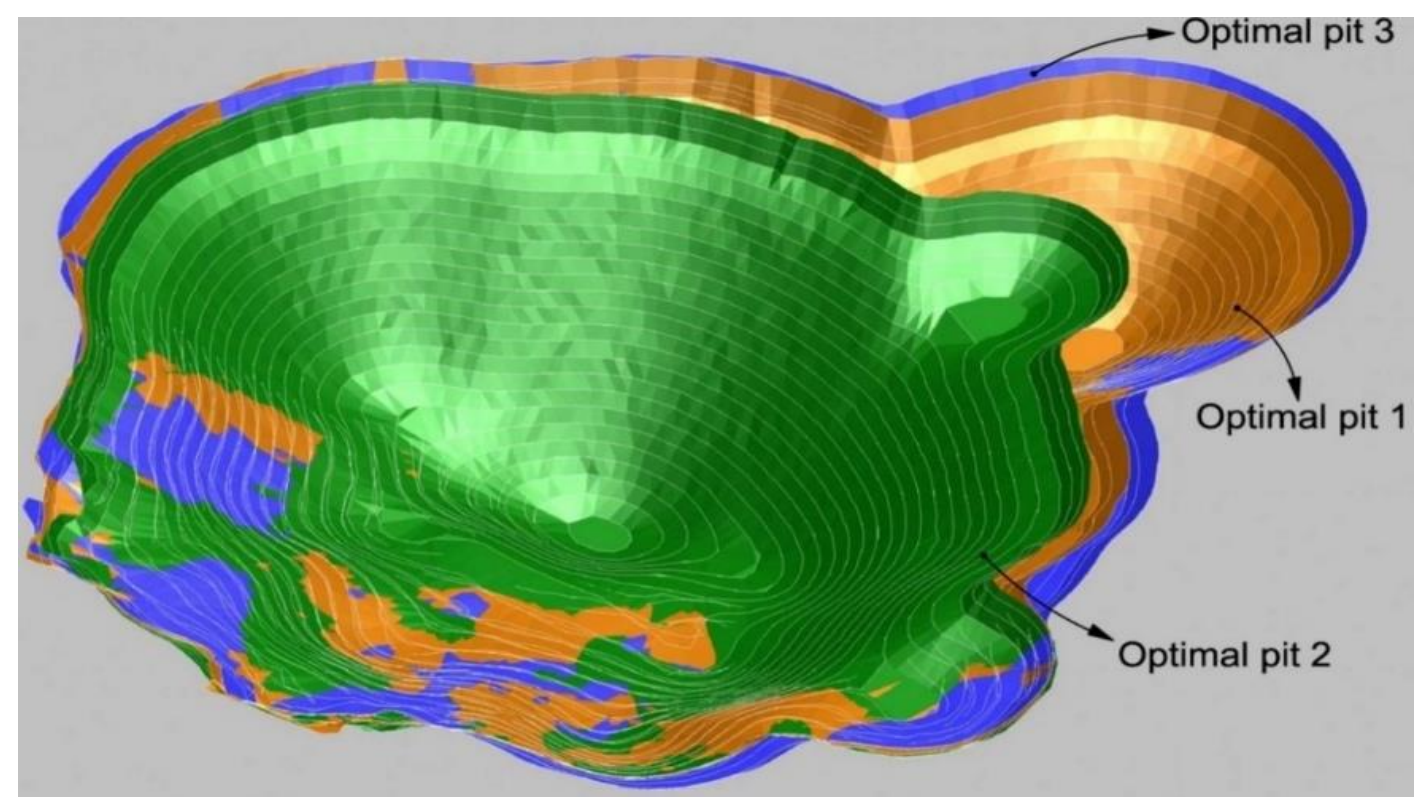

\section{Figure 5 - Generated optimal pits}

On the basis of generated pits, uncertainty assessment can be conducted. If we look at the value of ore mass, we can tell that, with a probability of $68,27 \%$ (probability distribution of $\bar{x} \pm \sigma$ ) the optimal pit will contain ore mass between 32.6 (Pit_2) and 36.95 (Pit_3) million tones. The difference between these two pits is just $13.3 \%$ (for ore mass). We can also compare ore mass from Pit_1 $\left(36.02 \times 10^{6} t\right)$ and Pit_3 $\left(36.95 \times 10^{6} \mathrm{t}\right)$, resulting to a difference of just $0.3 \%$. This means that the increase of EBV, to the value of $\bar{x}+\sigma$, practically does not affect pit design and optimal limits.

NPV has been calculated for every pit with the same parameters. Capacity for one year is set to $2 \times 10^{6}$ $\mathrm{t}$ and discount rate is $8 \%$. If we observe the NPV performance of pits, we can tell that with a probability of $68,27 \%$ (probability distribution of $\bar{x} \pm \sigma$ ) the optimal pit will have NPV between 192.2 (Pit_2) and 401.2 (Pit_3) million euros. In contrast to the case when we compared ore mass, the comparison of NPV value shows a big difference between pits. The difference between Pit_1 and Pit_2 is 51.1\%, between Pit_1 and Pit_3 is 38,2\% and for Pit_2 and Pit_3 the difference reaches $208.8 \%$. A big difference in NPV value is generated by the difference in calculated EBV for the pits.

In the end, we can conclude, that for a wide range of scenarios, optimal pit will be much more sensitive to NPV performance, than to probability to contain more or less ore mass.

\section{CONCLUSIONS}

This paper presents a hybrid model for calculating the EBV and generating optimal pits that can be used for uncertainty assessment. The presented model is a combination of both conventional (deterministic) and stochastic approaches. Furthermore, the developed model takes into account the uncertainty of parameters for determining EBV. The proposed methodology provides a practical method for approximation of EBV, with no need of numerous and time-consuming simulations. Function is determined on the basis of the comparison between a set of deterministically calculated and simulated EBV. Using this function, EBV for all other blocks (of the stochastic block model) is calculated. For an obtained EBV, using the LG algorithm, many optimal pits can be generated. Those pits in a plastic way, in a 3-D space, allows uncertainty assessment. Proposed hybrid model is universal in sense that it can be used for various deposits (coal, metal, etc).

All in all, it is clear that the uncertainty should not be ignored as it can have a major impact on the project success. The source of uncertainty should be incorporated in calculations in order to suggest more robust and realistic solutions. However, further investigation is required, for a better understanding of the possible improvements that stochastic solutions may have to offer, as compared to present conventional (deterministic) practices.

\section{REFERENCES}

[1] Horsley T. P, Dollar driven mine planning: the corporate perspective to operational mine planning, Australian mining consultant-AMC reference material, 2002.

[2] Morley C, Snowden V. and Day D, Financial impact of resource/reserve uncertainty. Journal of the South 
African Institute of Mining and Metallurgy, Volume 99.pp. 293-301, 1999.

[3] Erdem Ö, Güyagüler T. and Demirel N, Uncertainty assessment for the evaluation of net present value: a mining industry perspective, The Journal of The Southern African Institute of Mining and Metallurgy, Volume 112, pp. 405 - 412, 2012.

[4] Whittle D, The relation between economic design objectives and reserve estimates. Proceedings of the resources to reserves inputs seminar, AusIMM, Melbourne, 1997.

[5] Lerchs H, Grossmann I. F, Optimum Design of Open Pit Mines, CIM Bulletin. Canadian Institute of Mining and Metallurgy, Volume 58, 1965.

[6] Kolonja B, Stevanović D, Pešić M. G, Banković M, Kolonja Lj, Uncertainty in open pit optimisation, 5th International symposium Mining and environmental protection, Vrdnik, Serbia, 2015; pp.385-392.

[7] Stevanović D, Kolonja B, Stanković R, Knežević D, Banković M, Application of stochastic models for mine planning and coal quality control, Thermal Science, Volume 18, No. 4, pp. 1361-1372, 2014;

[8] Kolonja B, Lilić N, Stanić R, Using simulation and knowledge based approach for surface coal mine design in Yugoslavia, International symposium continuous surface mining, Freiberg, Germany, 2001.

[9] Godoy M, Dimitrakopoulos R A risk quantification framework for strategic mine, planning: method and application, Journal of mining science, Volume 47, pp. 235 - 246, 2011;

[10]Dimitrakopoulos R, Farrelly C. T. and Godoy M. C, Moving forward from traditional optimisation: grade uncertainty and risk effects in open pit mine design. Transactions of the IMM, Section A Mining Industry. Volume 111. pp. A82-88, 2002;

[11]Abdel S. A, Dimitrakopoulos R, Incorporating geological and market uncertainties and operational flexibility into open pit mine design, Journal of Mining Science, Volume 47, pp. 191-201, 2011;.

[12]Rendu J. M, Geostatistical simulations for risk assessment and decision making: the mining industry perspective. International Journal of Surface Mining, Reclamation and Environment, Volume 16. pp.122133, 2002.

[13]Baek Jieun, Choi Yosoon, Park Han-su, Uncertainty representation method for open pit optimization results due to variation in mineral prices, Minerals, Volume 6, Issue 1, 2016;

[14]Evatt G. W, Soltan M. O, Johnson P. V, Mineral reserves under price uncertainty. Resour. Policy Volume 37, pp. 340-345, 2012,

[15]Asad M. W. A, Dimitrakopoulos R, Implementing a parametric maximum flow algorithm for optimal open pit mine design under uncertain supply and demand, J. Oper. Res. Soc. Volume 64, pp. 185-197, 2013.

[16]Lane G. R, Terblanche M, Mayer G, Sasto N, Case study on quantitative risk modeling to obtain a realistic risk-adjusted project valuation. The Journal of The Southern African Institute of Mining and Metallurgy, Volume 113 pp. 181-190, 2013.

[17]Pit Optimiser Tutorial, Geovia, Dessault Systemes, SURPAC 6.1, 2006; Available at: http://www.gemcomsoftware.com/products/Surpac Palisade Corporation, @Risk (Version 6.1.2) [computer program] Palisade Corporation. 2013; Available at: http://www.palisade.com/risk/> [Accessed 5. June 2013].

[18]Stevanović D, Radović R, Malbašić V, Kolonja B, Optimization of final pit limits for open pit Buvač using the software package Whittle. International symposium Sustainable development of mining and energy industry ORRE 11, Serbia, 11-15 September, ISBN 978-86-7352-257-9, pp. 309-316, 2011.

[19]Malbašić V, Stevanović D, Čelebić M, Optimization of waste transportation system for open pit Buvač. Tehnika, No. 4, Belgrade, str. 545-552; ISSN 00402176, 2012.

[20]International monetary fund (IMF), Prices \& Forecasts, Monthly Data, Available at: http://www.imf.org/external/np/res/commod/index.aspx, [Accessed 10 July 2013] 


\section{REZIME}

\section{HIBRIDNI MODEL ZA PROCENU NEIZVESNOSTI U OPTIMIZACIJI POVRŠINSKIH KOPOVA}

Današnja ležišta često su mala, sa lošim kvalitetom i kompleksnom strukturom i geometrijom, što ih čini teškim za eksploataciju. Iz ovoga razloga, za ekonomski uspeh projekta, izuzetno je bitno uzeti u obzir mnogobrojne uticajne parametre. Značajan problem ovakvom pristupu je činjenica da je vrednost praktično svakog parametra neizvesna. Iz tog razloga neizvesnost kao pojava mora biti uključena $u$ proračune, kako bi se obezbedila realnija rešenja. U osnovi optimizacije granica površinskih kopova je ekonomska vrednost svakog bloka u modelu. Ekonomska vrednost bloka zavisi od mnogih neizvesnih parametra. Ovaj rad prezentuje model za proračun ekonomske vrednosti blokova u modelu i generisanje optimalnih kontura kopova koje se mogu koristiti za procenu neizvesnosti. Predloženi model je kombinacija determinističkog $i$ stohastičkog pristupa. Prezentovan model uzima u obzir neizvesnosti povezane sa parametrima koji određuju ekonomsku vrednost blokova. Takođe u radu je obrađeno $i$ upoređenje između optimalnih kontura generisanih na osnovu deterministički i stohastički proračunatih vrednosti blokova u modelu. Ovo upoređenje može se iskoristiti za procenu neizvesnosti povezane sa optimizacijom granica površinskih kopova.

Ključne reči: optimizacije granica površinskih kopova, ekonomska vrednost bloka, procena neizvesnosti, stohastički model 